\title{
THE NEW ONTARIO JUDICIAL ALTERNATIVE DISPUTE RESOLUTION MODEL
}

\author{
PETER BOWAL
}

The author introduces the new ADR Pilot Project currently being tried in the Ontario Court of Justice (General Division). Taking place in Toronto, the project is aimed at avoiding civil litigation. It involves $A D R$ referral and management after filing of the Statement of Defence. First, the parties must meet. If the dispute remains unsettled, statements are submitted by the parties. The parties and counsel then attend an ADR session, which can be a mediation, mini-trial, or neutral evaluation. The advantages and disadvantages of the project are then detailed, for the parties, the public interest, and otherwise.

The author notes that the pilot project stresses many of the same values that are dominant in provincial arbitration legislation. However, there are also significant differences between the schemes.

In the end, the author is optimistic for the success of the project, but cautions that more time must pass before any meaningful assessments can be made.
$L$ 'auteur présente le nouveau projet pilote d'ADR actuellement utilisé $\dot{a}$ la Cour de justice de l'Ontario (Division générale). Mis en auvre à Toronto, ce projet vise à éviter les procès civils. Il implique le renvoi à l'ADR et la gestion par ce biais après le dépôt de l'exposé de la défense. Les parties doivent d'abord se rencontrer. Si le litige persiste, les deux parties soumettent leurs exposés. Les parties et leurs représentants assistent ensuite à une séance d'ADR, qui peut être une médiation, un mini-procès ou une èvaluation neutre. Les avantages et les inconvénients du projet sont ensuite examinés en détails, dans la perspective des parties et de l'intérêt public, notamment.

$L$ 'auteur note que le projet pilote met l'accent sur la plupart des valeurs véhiculées par les lois sur l'arbitrage de la province. Cependant, il existe aussi des différences significatives. $L$ 'auteur se montre optimiste quand au succès du projet, mais estime que seul le temps permettra d'en juger véritablement la valeur.

\section{TABLE OF CONTENTS}

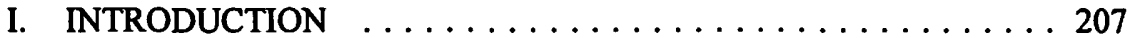

II. PILOT PROJECT $\ldots \ldots \ldots \ldots \ldots \ldots \ldots \ldots \ldots \ldots \ldots \ldots \ldots \ldots$

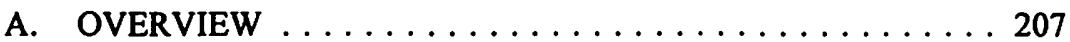

B. FORMAT OPTIONS $\ldots \ldots \ldots \ldots \ldots \ldots \ldots \ldots$

C. STRENGTHS OF THE ONTARIO MODEL ....... 209

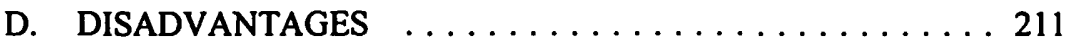

III. RELATIONSHIP TO ARBITRATION

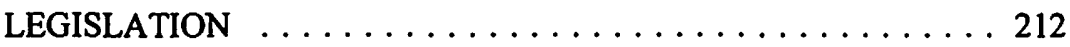

IV. CONCLUSION $\ldots \ldots \ldots \ldots \ldots \ldots \ldots \ldots \ldots \ldots \ldots \ldots \ldots \ldots \ldots \ldots$

Associate Professor, Faculty of Management, University of Calgary. Financial Assistance for this research from the Future Fund of the Canadian Bar Association is acknowledged and gratefully appreciated. 
Discourage litigation. Persuade your neighbours to compromise whenever you can. Point out to them how the nominal winner is often a real loser - in fees, expenses, and waste of time.

- Abraham Lincoln

\section{INTRODUCTION}

The great majority of civil disputes in Canada are not resolved by litigation. Of all actions commenced, it is not surprising that about only 5 percent actually ever go to trial. ${ }^{1}$ Most conflicts which are consensually determined benefit from methods other than formal court process. The term Alternative Dispute Resolution ("ADR") embraces a broad range of mechanisms and processes to assist parties in resolving differences. These include such traditional procedures as arbitration, mediation and simple negotiation.

A new model has been launched by the Ontario Court of Justice (General Division). ${ }^{2}$ An ADR Pilot Project offers disputants a timely and cost-effective alternative to litigation. This article examines Ontario's new venture and how it differs and contributes to the existing state of ADR in Canada.

\section{PILOT PROJECT}

\section{A. OVERVIEW}

The Ontario Court of Justice (General Division) and the Ministry of the AttorneyGeneral have initiated a two year pilot project of a court-based ADR service for the metropolitan Toronto area. Designed to provide the framework to resolve civil disputes without going to trial, the ADR Centre handles new civil actions, cases previously in the civil inventory and matters transferred from the Commercial List. ${ }^{3}$

The ADR pilot project is an additional step in the court process. Despite creating another layer, the goal of this project is to:

provide enhanced, more timely and more cost effective access to justice for both defendants and plaintiffs. It is designed to provide additional court services and significantly improved access to justice."

This objective is achieved by ADR intervention after a Statement of Defence is filed but before trial. A successful ADR intervention will obviate court process.

G. Watson et al., eds., Dispute Resolution and the Civil Litigation Process (Toronto: Emond Montgomery, 1991) at 3.

2 "Practice Direction - Alternative Dispute Resolution - 1994" (1994), 16 O.R. (3d) 481.

$3 \quad$ Ibid. at 481.

$4 \quad$ Ibid. at 483 . 
Cases are judicially referred to the ADR Centre, where they are assessed by a dispute resolution officer. Then, with the consent of the parties, the case is referred to ADR processes which are administered by a dispute resolution officer or a judge.

This system presents an opportunity to resolve the dispute without resorting to litigation which can be expensive, intimidating, time consuming, inflexible and destructive of relationships. First, even before attending the ADR Centre, the parties are required to meet to discuss the dispute. With minimal cost and time, the dispute can be settled at this stage. If it is not settled, the parties then submit a statement containing the central factual and legal issues to the ADR Centre which statement becomes the basis for the ADR sessions. ${ }^{5}$

The parties and their legal counsel, if any, then attend an ADR session. There are three options from which the parties can select.

\section{B. FORMAT OPTIONS}

\section{Mediation}

A judge or dispute resolution officer assists the parties to reach a mutually acceptable resolution of that dispute. This process is informal. The parties have the opportunity to give evidence and arguments. The mediator helps in this process but does not have the power to render a decision. ${ }^{6}$

\section{Mini-trial}

In a mini-trial, opposing counsel present their best case to the parties or to a representative of the parties with authority to settle the case and to a judge of the Court who moderates the presentations and renders a non-binding opinion as to the probable resolution of the dispute. The ground rules are usually agreed upon by the parties. This most often involves an agreement that there will be no formal examination and crossexamination of witnesses, and that the rules of evidence will not be applied. ${ }^{7}$ This non-binding decision as to the probable outcome provides a further incentive for the parties to settle. ${ }^{8}$

Ibid. at 485 (s. 4.2 of the Alternative Dispute Resolution Pilot Project Procedures) [hereinafter the "Procedures"]; at 488 (Form 2).

6 J. Folberg \& A. Taylor, Mediation (Jossey-Bass: San Francisco, 1984) at 9, define mediation as: the process by which the participants, together with the assistance of a neutral person or persons, systematically isolate disputed issues in order to develop options, consider alternatives, and reach a consensual settlement that will accommodate their needs. Mediation is a process that emphasizes the participants' own responsibility for making decisions that affect their lives. It is therefore a self-empowering process.

W.D. Brazil, Effective Approaches to Settlement: A Handbook for Lawyers and Judges (Clifton, N.J.: Prentice Hall, 1988) at 55.

- S.G. Fisher, "The Mini-Trial: A Guide to Success" in D.P. Emond, ed., Commercial Dispute Resolution: Alternatives to Litigation (Aurora: Canada Law Book, 1989) 203 at 207: "the objective of [the mini-trial] is to give the parties a chance to reach an informed settlement or at worst an informed decision to litigate." 


\section{Neutral evaluation}

In this option, a judge or dispute resolution officer evaluates the relative strengths and weaknesses of the positions advanced by the parties and the probable outcome at trial, and advises the parties accordingly. This evaluation is non-binding, but again it provides an incentive for parties to settle.

After any of these procedures, if an agreement is reached, it is reduced to writing and signed by the parties or their counsel. The agreement is filed with the ADR Centre and can be filed with the Court. ${ }^{9}$ If, however, the dispute is not resolved, the parties proceed to trial and the matter is handled in the traditional litigation process. ${ }^{10}$

\section{STRENGTHS OF THE ONTARIO MODEL}

The aim of this pilot project is to provide a forum that supplements the formal court system in such a way as to reduce the number of cases that go to trial. The option is only available once a Statement of Defence has been filed. It is, therefore, the parties' intention to go to court to settle the dispute when they enter this form of ADR. There are advantages for both the parties and for the province and public in utilizing the ADR process.

\section{Advantages for the Parties}

- This project is designed to resolve the dispute at an early stage. Rather than setting a court date that is months away, the parties get to deal with their conflict in a much more timely fashion. A successful example of this handling of disputes at an early stage is found in the construction industry, where many large projects establish an ADR Board to deal with problems as they arise rather than waiting until the end of the project to litigate."

- Time and money are inextricably linked in litigation; the more time consumed, the more money it will cost. An ADR agreement is much less costly than the traditional method of litigation, particularly if there are appeals involved. The costs of litigation are much higher than ADR costs to the parties. D.P. Emond notes:

one reason why litigation is so expensive is that it not only demands a high standard of proof but it also includes a number of complex procedural and evidentiary provisions designed to ensure that the parties are afforded a full opportunity to make their case. ${ }^{12}$

" See P. Sandori, "Alternative Dispute Resolution" (1993) 6 C.L.R. (2d) 231.

12 D.P. Emond, "Alternative Dispute Resolution: A Conceptual Overview" in Emond, ed., supra note 8,1 at 7 . 
- If the ADR session is a fraction of the cost of traditional litigation, it must also take much less time to resolve the dispute. If, for example, the parties can reach an agreement at the mandatory meeting before attending an ADR session, the entire process may take but a few hours. Even if the dispute goes to the next stage and the parties elect a neutral evaluation, this process will be much less time consuming than normal litigation.

- The flexibility of resolving a dispute using the ADR process allows the parties to arrive at a suitable solution. The dispute is not resolved by a judge who renders a decision to which the parties are bound. A judge can only choose between damages and injunctive relief in a civil matter. An ADR agreement can be custom-made to satisfy both parties in any form they feel appropriate.

- Access to justice is improved by providing a mechanism that resolves a dispute in a way that satisfies both parties and in which they believe a just result has been reached.

- The ADR session is informal and non-intimidating. The parties play a major role in the outcome. The traditional model of litigation is antithetical to this flexibility, as Emond states:

[N]ot only do the parties not speak on their own behalf - that is done by hired professionals - they do not speak to each other. Instead, they speak to a third party decision-maker. The intimacy and conjoining effect of face-to-face contact is replaced by the alienating and disjoining effect of a charade between strangers.... The parties participate, if at all, as well-rehearsed witnesses in a pre-set drama. For many, the result is a sense of alienation and frustration. They are mere observers, trying to comprehend the symbolism and the jargon of an incomprehensible, highly formalistic charade. ${ }^{13}$

2. Public Interest Advantages

- The project is funded through the Ministry of the Attorney-General's "Investment Strategy." The end goal, however, is one of actually adding resources to the Ontario justice system. If disputes can be resolved at the ADR level, the significantly more expensive litigation process is avoided and money is ultimately saved. Much of the expense of litigation is attributed to judges' and administrative staff salaries and other expenses borne by society.

- By diverting disputes through the ADR level, the number of cases that do go to trial is reduced. This results in a smaller backlog so that parties who are unable to resolve their dispute or do not agree on an ADR session can get a court date sooner. 
- A quicker court appearance will significantly reduce problems inherent in the traditional model of litigation, such as the availability of or the faded memories of witnesses.

\section{Miscellaneous Advantages}

- Judges and dispute resolution officers are trained in ADR techniques, including assessment, neutral evaluation, mediation and mini-trials. ${ }^{14} \mathrm{~A}$ thorough grounding in job functions before the project begins will reduce the possibility of parties becoming disenchanted with this "alternative" to the formal court process if it is perceived as haphazard or disorganized.

- The ADR process offers a choice of techniques. This flexibility offers the parties even greater control over their dispute resolution.

- An ADR Users' Committee, consisting of practitioners who are familiar with ADR, will meet regularly with the Court's representatives to consider improvements to the project's operation. ${ }^{\text {is }}$

\section{DISADVANTAGES}

The biggest disadvantage is that there is no assurance that the "R" in ADR will be attained. Although the parties consent to using the ADR process, there is no binding decision given. A compelled binding decision is the great advantage of litigation and arbitration. What contributes to making litigation unattractive, may also be its greatest virtue. The inability to conclude a resolution is the weakness of all non-arbitration ADR methods. Under this particular ADR model, parties who are not satisfied at the end of the process file a Certificate of Inability to Resolve through ADR (Form 4). The matter then proceeds to trial. The result would then be the more costly and time consuming process for the parties.

If the dispute ends up going to trial, nothing that came out of the ADR process can be used at trial. Section 5.1 of the Procedures states:

Prior to participating in an ADR session, the parties will be required to enter into and file at the ADR Centre an agreement in Form 3, indicating their agreement that

(a) statements made and documents produced in an ADR session and not otherwise discoverable shall not be subject to disclosure through discovery or any other process and shall not be admissible into evidence for any purpose, including impeaching credibility.... ${ }^{16}$ 
This appears to constrain the normally broad scope of discovery. ${ }^{17}$ Although privacy and confidentiality should be protected, this pilot project is integrated into the judicial system. One might question the overall wisdom of suppressing any statements or documents from the ADR process from use in trial. Instead, the ADR process could be used as a part of, or supplementary to, discovery.

This section creates two distinct processes: the ADR session and the litigation method. Section 5.1 effectively makes for duplication in work if the dispute goes to trial. In litigation, the parties must start all over from the very beginning. This may actually increase costs.

Another disadvantage results from achieving the above-mentioned advantages such as cost, time and flexibility. The ADR sessions do not provide for the adversarial tools of cross-examination, testifying under oath, formal discovery and other methods of surfacing the truth. However, this disadvantage must be weighed against the numerous advantages such informality creates. If, indeed, a dispute cannot be resolved at the ADR stage then these tools become available at the trial level. However, all the advantages that the ADR session provides are lost at that point.

\section{RELATIONSHIP TO ARBITRATION LEGISLATION}

Arbitration is the settlement of disputes by a decision, not of a court of law, but by one or more persons, who are called arbitrators and who render a formal and binding decision. ${ }^{18}$ Most of the provincial Arbitration Acts are very similar, as they were all based on the Arbitration Act passed in the United Kingdom. ${ }^{19}$ However, Ontario and Alberta have recently passed new arbitration statutes which better suit conditions in Canada today. ${ }^{20}$ Examining the Ontario statute that came into force January 1, 1992, one notes many sections that reflect the same objectives in the Ontario ADR pilot project. Party autonomy, efficiency and equal and fair treatment underlay the two new Acts. ${ }^{21}$

Despite the pilot project resembling the arbitration process, arbitration is most often associated with corporations contracting with one another. The Ontario pilot project, on the other hand, aims at resolving the common civil dispute. ${ }^{22}$ The pilot project and the

See e.g. Alberta Rules of Court, r. 200. See also Drake v. Overland (1979), 107 D.L.R.

(3d) 323 (Alta. C.A.); Tiedmann v. Basiuk (1978), 4 Alta. L.R. (2d) 12 (S.C.T.D.).

S.P. Doyle \& R.S. Haydock, Without the Punches: Resolving Disputes Without Litigation (Minneapolis: Equilaw, 1991) at 8-9. "New Legislation for Domestic Arbitrations" (1993) 21 C.B.L.J. I.

22 Note that initially this pilot project will not be dealing with motor vehicle negligence or family law cases. See supra note 2 at 482. 
various provincial arbitration Acts $^{23}$ both circumvent the traditional court process but there are significant differences.

Arbitration usually arises from an agreement before a dispute arises. Normally, an arbitration clause will be written into the contract. The pilot project, however, only takes effect once the parties have filed the Statements of Claim and Defence. Thus, both processes are consensual but the consent emerges at different times.

The most significant difference is the outcome of the processes. After arbitration, a binding decision is rendered. None of the processes in the pilot project (mediation, mini-trial and neutral evaluation) have the power to produce a binding result. When the parties, therefore, enter into arbitration they are accepting a decision as final, ${ }^{24}$ whereas in an ADR session the parties know they can always resort to court proceedings if a resolution is not reached. Their conduct of the ADR will depend upon how they perceive their chances at trial; ADR works best when this perceived risk is held in more or less equal proportions by the disputants.

Parties involved in arbitration are not entirely precluded from ultimate court process. Nevertheless, the manner of proceeding is different from that for a failed ADR session. "Arbitration awards will always be subject to judicial review on the basis of [arbitrator] misconduct, infringement of natural justice or [deceit]." 25 The courts are highly protective of their jurisdiction over the administration of justice and readily dismiss an attempted ouster of this inherent jurisdiction. ${ }^{26}$

\section{CONCLUSION}

The Ontario pilot ADR project began in March, 1994. Time will obviously be the best indicator as to whether this endeavour is a success. The objectives are all linked. Therefore, if the goal of saving time and money for the parties is achieved, so too will be the goals of reducing the number of cases that go trial and reducing the costs associated with a trial. The pilot project has been well planned. It has borrowed from the structure of many U.S. models which have proven to be highly successful. There has been an effort to prepare persons involved in the process ahead of time, instead of leaving them to learn on the job.

The two critical elements to watch for are the number of cases that go through the ADR sessions and that end in agreement and the success of the enforcement of the

Arbitration Act, S.A. 1991, c. A-43.1; Commercial Arbitration Act, S.B.C. 1986, c.3; Commercial Arbitration Act, R.S.C. 1985, c.17 (2nd Supp.); Arbitration Act, R.S.M. 1987, c. A-120; Arbitration Act, R.S.N.B. 1973, c.A-10; Arbitration Act, R.S.N. 1990, c. A-14; Arbitration Act, R.S.N.W.T. 1988, c. A-5; Arbitration Act, R.S.N.S. 1989, c.19; Arbitration Act, S.O. 1991, c.17; Arbitration Act, R.S.P.E.I. 1988, c. A-16; Arbitration Act, S.S. 1992, c. A-24.1; Arbitration Act, R.S.Y.T. 1986, c.7.

24 See e.g. the Ontario Arbitration Act, ibid., s. 37.

2s Alberta Law Reform Institute, Dispute Resolution: A Directory of Methods, Projects and Resources (Edmonton: ALRI, 1990) at 24. Scott v. Avery (1856), 25 L.J. Ex. 308; 5 H.L.C. 811 (H.L.). 
agreements. Ultimately, as the Practice Direction concludes, this model's success, as is the case for all of ADR, will "depend on the cooperation of all parties to any dispute, and their counsel." 27 